\title{
Continuity or Change in the Infrastructure Turn? Reform of the Technicians' Realm in a World Bank Dam
}

DOI:

10.1057/s41287-019-00232-4

\section{Document Version}

Accepted author manuscript

Link to publication record in Manchester Research Explorer

\section{Citation for published version (APA):}

Dye, B. J. (2019). Continuity or Change in the Infrastructure Turn? Reform of the Technicians' Realm in a World Bank Dam. European Journal of Development Research. https://doi.org/10.1057/s41287-019-00232-4

\section{Published in:}

European Journal of Development Research

\section{Citing this paper}

Please note that where the full-text provided on Manchester Research Explorer is the Author Accepted Manuscript or Proof version this may differ from the final Published version. If citing, it is advised that you check and use the publisher's definitive version.

\section{General rights}

Copyright and moral rights for the publications made accessible in the Research Explorer are retained by the authors and/or other copyright owners and it is a condition of accessing publications that users recognise and abide by the legal requirements associated with these rights.

\section{Takedown policy}

If you believe that this document breaches copyright please refer to the University of Manchester's Takedown Procedures [http://man.ac.uk/04Y6Bo] or contact uml.scholarlycommunications@manchester.ac.uk providing relevant details, so we can investigate your claim.

\section{OPEN ACCESS}




\title{
Continuity or Change in the Infrastructure Turn?: Reform of the technicians'
}

\section{realm in a World Bank Dam}

\author{
Abstract (147 Words)
}

Development in Africa is undergoing an infrastructure turn, no more so than in resurgent dam building. But how are new projects planned and constructed? Are we seeing repetition of much maligned practices that underestimated economic, environmental and social costs, or have past critiques changed infrastructure building in the $21^{\text {st }}$ century? Using the concept of the technician's realm that describes short-sighted and expert-centric $20^{\text {th }}$ century practices of dam building, this article analyses the incorporation of reformist ideas about knowledge production, mitigation and compensation. It uses a detailed case study of the Rusumo Dam, and examines the decision-making processes of the World Bank and a new dam-building organisation, Nelsap. Significantly, this case involved a marked design revision to reduce impact, but also top-down and depoliticising impact assessment and policymaking. It therefore demonstrates nuanced change in the infrastructure turn, the incorporation of reform and continued relevance of past critiques.

Key Words: Dam Resurgence, World Bank, Reform, Development, Infrastructure, Impact Assessment, Rusumo Falls Dam, Nelsap, Hydropower 


\section{INTRODUCTION}

Particularly in Africa, development has taken an infrastructure turn (Nugent, 2018). Partly inspired by their economic transformation, governments in Africa are turning to the emerging powers, and particularly China, to finance and build ambitious development projects. Equally, as Mawdsley's (2018) analysis of the UK's Department for International Development shows, traditional development organisations are also increasingly focused on infrastructure and industrial policy. She particularly demonstrates attention shifting from smaller poverty-reduction development projects towards economic growth targets; something reflected in the Millennium Development Goals (MDGs) as oppose to the economic infrastructure elements of the Sustainable Development Goals (SDGs). This trend in infrastructure construction and the principles of development harks back to the dominant development ideas of the mid twentieth century; of strong state-led intervention that aimed to deliver economic growth through large-scale projects, especially in agriculture, energy and transport infrastructure. But with this apparent trend towards building large-scale infrastructures, is this new trend of infrastructure construction replicating critiqued past practices? How are 'traditional' development actors like the World Bank operating in this new infrastructure turn?

This article studies such questions through perhaps the premier infrastructure project, large hydropower dams. More than other infrastructure, dams' size and grandeur suggests the arrival of modernity and the promise of development, whilst their sophisticated engineering necessarily gives a prominent role to experts. Dam building has closely followed trends in international development. Post-World War Two, developing countries led an infrastructure boom which rapidly declined from the 1980s. From roughly the mid-1990s to the mid-2000s very few dams were constructed, particularly in Africa. Concerns about the severity of social and environmental impacts drove this near-cessation in construction, as did questions over 


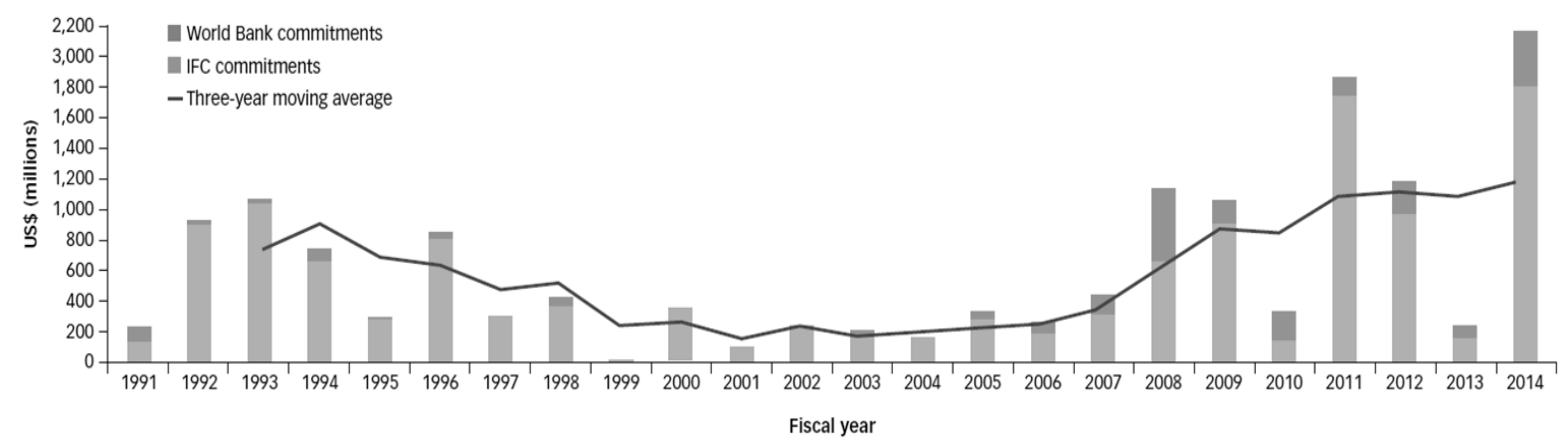

Figure 1 World Bank Group Lending for Hydropower Development, Fiscal Years 1991-2014 (Source: Rex et.al., 2014, p3)

dams' economic effectiveness, with studies indicating the underperformance of dams' hydropower generation and irrigation supply. However, despite essentially no change in technology, dam construction has returned (Zarfl et al., 2015). The World Bank is an important actor initiating these policy changes. Having been perhaps the key funder of dams from the 1960s, the World Bank started to withdraw in the 1980s (McCully, 2001, p. xvi). This is symbolised by retreats from notable projects like India's Narmada Dam (Goldman, 2005) and is further demonstrated by the dramatic fall in dam funding to 0 loan approvals in 1999, shown in figure 1. However, this trajectory reversed. Following policy statements supporting hydropower construction in 2003, 2009 and 2013, dam finance increased. Thus, particularly amongst so-called traditional donor organisations, is there change in dam building's return? To what extent is the apparent 'infrastructure turn' replicating the past or have critiques translated into the adoption of reform?

This article studies these questions using an in-depth case study of the World Bank financed Rusumo Falls Hydropower Project (hereafter Rusumo Dam) on the Rwanda-Tanzania border. It is financed by the World Bank and implemented by a new river basin authority, the Nile Equatorial Lakes Subsidiary Action Programme (hereon Nelsap); an agency of the Nile Basin Initiative. The dam started construction at the end of 2016 after a decade of study, local engagement and compensation schemes. Usefully, Rusumo Falls Dam consequently allows a rare study of what in the author's judgement appears to be 'best practice' in the infrastructure 
turn. Moreover, the case fills a gap in detailed empirical studies of this infrastructureresurgence era, particularly by the World Bank where the existing literature tends to be primarily critical (Baird et al., 2015; Goldman, 2005; Moore et al., 2010). Nelsap's role adds further importance. It is a new type of river basin authority, one originally initiated by the World Bank alongside other donors in 1999 to embrace 'good governance' and 'best practice' ideas around international water management, but also to unlock infrastructure projects. The Rusumo Dam is the first infrastructure project constructed by this new institution. Overall then, this case study constitutes a particularly good opportunity to ground examination of new and returned infrastructure actors and consider changes in this era's practices.

The article proceeds by explaining the concept of the technician's realm, an analytical device that describes the policy practices of past-era river basins and therefore allows assessment of changes to implementation practices. It then turns to the case of Rusumo Dam, assessing its design, knowledge production and mitigation. Broadly, this project demonstrates that change has occurred: there are new ambitions to reduce the negative impacts of dams amongst relevant officials in the Bank and Nelsap. However, rather than wholesale change, this resurrected dam project involves many of the expert-centric, depoliticising practices of the technician's realm. Consequently, this pattern of continuity and change suggests that the incorporation of reformist ideas can matter, but rather than displacing pre-existing modes of 'doing development', they are merely added.

This article was founded on primary research carried out over two field trips in 2015-2016 that were part of a thesis and included 100 interviews with relevant officials from ministers to mid-ranking civil servants in Rwanda and Tanzania. In particular, interviews engaged with Nelsap, the energy utility companies, energy ministries and environmental assessors. In 2017, interviews were also carried out at the World Bank (see quoted interviews in appendix). This 
method is most appropriate for investigating the complexities of decision-making processes and the values informing it. The methodology was also crucial in the context of authoritarian countries with limited public information. To triangulate data, planning and news reports relating to the project were analysed. Whilst the author has carried out research on wider dam-building and electricity-sector policy making in Rwanda and Tanzania, it does not feature strongly here because the governments handed authority to Nelsap and thereby played a lesser role in implementation. In addition, 52 local-level interviews with Rwandan and Tanzanian residents were conducted using a purposive sampling method that involved deliberately selecting interviewees to capture the gamut of wealth, poverty, geography, gender and age in the Rusumo valley. Interviews were typically between 30-40 minutes, often extending over an hour and are listed in the appendix. This provided an important dataset enabling verification and nuancing of official reports. To avoid the researcher's biases and limited contextual knowledge, inductive methods were used that involved participants leading guided field walks that explained livelihoods and changes to the affected landscape. Given these methods, data was analysed using an iterative process of rereading, sifting, sorting and triangulating, from which key experiences emerged.

\section{DAMS AND THE ERAS OF DEVELOPMENT POLICY}

Thinking about the best way to achieve development, and about the potential role of infrastructure in socio-economic progress, has shifted over time. In the simplified schema of Hart (2001), an important change occurred in the 1980s when neoliberal ideas replaced the state-centric modernisation ideology of the 1950s-1970s. The latter became dominant after World War Two, under the influence of Socialist and Keynesian thought. Modernisation development schemas prescribed a focus on the state and stressed its ability to change the economy and society (Leys, 1996; Rist, 2010). This involved economic ideas about the importance of rationalising economic activity 'from above', the creation of large projects and 
the application of the latest scientific advances (Scott, 1998). Key theorists in this era (e.g. Lerner, 1958) were also focused on the need for social change, the importance of breaking so-called traditional ways of thinking and acting, which they blamed for creating supposedly backward, inefficient, unproductive agriculture and manufacturing. Policies therefore focused on the introduction of 'modern' technologies and ways of working. In agriculture, green revolution programmes sort to mechanise farming, increasing productivity through creating larger, rationalised, industrial farms the adoption of technologies from fertilisers to tractors. Another focus was on grand projects of industrialisation. The ideas and policies of this era were not homogenous: Rostow's (1960) capitalist stages-of-development model aimed for a consumer society, an ambition which contrasts with the Marxist-inspired dependency theorists prescribing a bigger role for a protectionist state (Rist, 2010). Despite such variations, modernisation ideas frequently stressed the importance of infrastructure as a key ingredient to achieving such modernisation.

\section{Dams and the Technician's Realm}

Modernisation ideas about development particularly influenced dam-building policies: the infrastructure could deliver electricity for industrialisation and urbanisation, and water for irrigation. Moreover, dam's concrete monumentality had symbolic importance. Their size signifies the power of the government, their technological sophistication embodies images of modernity, as does their ability to rationalise rivers (Kaika, 2006). In line with beliefs about the state's preeminent development role, the importance of science and ability of experts, this era involved a set of dam building practices that empowered technicians in river basin institutions. The exemplar dam building organisation inspiring such technicians' realms was the Tennessee Valley Authority (TVA). It was designed to have a total mandate for valley transformation, changing the supposedly backward hillbillies of the mid-west to modern citizens through industrialisation underpinned by hydropower dams (Klingensmith, 2007). 
This term, the technicians' realm, builds on Ellul's (1964) conceptualisation of 'technique', defined as the practices that, through aiming to increase efficiency, render nature and society subservient to technology and the decisions of experts. In practise this involves a planning process that narrowly defines progress as involving concrete infrastructure and the implementation of technology, that sees efficiency as only applying to human-created environments and activities. This explicitly ignores the value of any pre-existing system and therefore overlooks trade-offs stemming from development projects. Byrne and Toly (2006) and Agbemabiese and Byrne (2005) apply Ellul's work to electricity and dam-building, analysing the primacy given to engineers in dam-project decision-making and the consequent exclusion of situated, local knowledge and of livelihood concerns. The empowering of experts to create knowledge and produce designs that exclusively focus on modern technology's implementation side-lines engagement with positively or negatively affected peoples whilst the exclusive appreciation of the built environment breeds degrees of shortsightedness to the trade-offs of a project: "Social consequences are relegated .... to the status of problems-to-be-solved" through rationally derived solutions (Byrne and Toly, 2006, p. 21). Such practices contrast with those who assert the political nature of infrastructure that negatively affects some whilst benefiting others. Crucially then, this concept involves the empowerment of a particular type of expertise, one whose worldview is relatively narrow and focused on concrete engineering. This is described by Li (2007) as rendering technical. She uses this to conceptualise anti-political processes whereby experts define problems and circumscribe their boundaries in such a way that their interventions becomes the solution, and particularly applies it to poverty reduction strategies whereby 'experts' focus on symptoms rather than the social processes causing poverty. The technician's realm builds on this work to describe a project's planning phase when knowledge about the local environment and impacts is produced and implementation methodology formed. 
River Basin Organisations inspired by the Tennessee Valley Authority (TVA) best exemplify the technician's realm concept. Facsimiles include India's Damodar Valley Corporation (Klingensmith, 2007), this case study's Kagera Basin Organisation (KBO) and Ghana's Volta River Authority. Agbemabiese and Byrne (2005) argue that the latter's construction of Akosombo Dam embodies Ellul's concept of technique as engineers were tasked with discerning compensation, a process described as technological optimising that had little involvement from, or accountability to, displaced communities. Thus, empowering somewhat autonomous hydrocracies of technicians (Molle et al., 2009, pp. 328-245) leads to a 'development-from-above' model and, as Klingensmith (2007) argues, scientific approaches to progress where local concerns or alternative development ideas are absent. Adams (1992, p. 106) echoes this critique, claiming that river basin planners often 'lack ... understanding of existing environments and their uses', particularly the complex political ecologies that underpin smallholder livelihoods. The technician's realm therefore describes the institutionalisation of hydrocracy principles that understand dams as inherently developmental and assert the necessity of practices empowering experts, depoliticising decision-making and excluding local communities and their situated knowledge from influencing a project's governance.

Of relevance to this past dam building era, and to the theorising of the technician's realm, is Scott's (1998) thesis of high modernism. In brief, he conceptualises the past development era as involving an ideology with two key tenants: Firstly a belief in the binary of backward traditional, smallholder-farming livelihoods against modern industrial ones, and relatedly, a conviction in the binary of scientific technical knowledge against what has been called indigenous knowledge; that is knowledge that is not derived from scientific methodologies or formally codified. As an ideology, high modernism prescribes total societal, economic and ecological transformation. Consequently, it requires a significant degree of ruthlessness, 
uncompromising authoritarianism and a highly capable state, a standard which means that high modernist plans are rarely implemented in full. Moreover, it is important to treat high modernism as an ideology with specific idea-practices, not a panoptic analytical tool that homogenises all development efforts as negative. What Scott and others (e.g. Ferguson, 1994) usefully provide is an ideational conceptualisation of key policies in the past development era and the central assumptions behind these policy prescriptions.

\section{Critiques of modernisation and the rise of neoliberalism}

The 1980s started a shift away from such state-led, modernisation approaches to development (Leys, 1996). Reflecting a global political shift, the 'Washington Consensus' grew which preferenced a liberalised competitive market without trade barriers. This was premised on seeing the state in a more negative light, as the creator of market distortions and debilitating tax and regulation (Hart, 2001). Whilst institutions like the International Monetary Fund (IMF) and World Bank and their Structural Adjustment Programmes tended to push this agenda, Harrison (2001) also points out that developing countries' politicians and civil servants frequently imbibed such ideas. With the emphasis on monetary and liberal economic policy, and a reduced state, traditional development donors shifted from financing infrastructure projects. The small is beautiful thesis (Schumacher, 1993) provided rationales for this, contrasting large-scale economic interventions (painted as ineffective and the cause for indebtedness) with more efficient and smaller-scale projects. A further ideational shift started in the 1990s as international development took a 'social turn' (inspired by Stiglitz (2002) and others). This orientated efforts towards a focus on poverty alleviation and goals in education, sanitation, health and the environment.

Dam-building policies reflected these critiques. Whilst the twentieth century is replete with examples of dams underpinning economic activity (e.g. the electricity of Kariba Dam for Zimbabwe and Zambia or Akosombo Dam's for Ghana) evidence of the infrastructure's costs 
mounted. This included economic studies which demonstrated dams' frequently poor return on investment. For instance, Singh's database of Indian dams concludes that their economic costs have been far greater than their benefits (Singh, 2002). Moreover, dams' socioecological record is frequently underestimated. Dams have displaced significant numbers of people, conservatively estimated by Scudder (2012) to be 40 to 80 million. Scudder asserts the importance of this figure in light of his comprehensive database of dislocated people which demonstrates the slim chances of communities recovering their former economic and social levels. Such research shows the frequent inadequacy of compensation measures, even in cases of meaningful mitigation efforts. Dams also affect socio-ecological systems, meaning the biospheric functions that support ecologies and livelihoods. However, knowledge-production in dam assessments has frequently failed to appreciate such systemwide impacts. Adams (1992) finds practices in the 1980s focusing most on the direct, bounded impacts of reservoirs rather than those of the wider river system and particularly dams' downstream impacts. This overlooks the way the river can transmit nutrients and water that underpin farming, fauna and flora, particularly in basins with a marked seasonal pulse and dry-season recession agriculture along river banks.

As a result, in 1999, the economic, social and environmental record in dam building, and in order to resolve increasingly effective protests, pro and anti-dam actors instigated a sciencepolicy interface aiming to chart more sustainable, less poverty-inducing dam-building practices. Called the World Commission on Dams (WCD), it brought together researchers, officials and activists, creating an evidenced-based set of reform measures that prescribed holistic assessment of the impacts of dams, more rigorous consideration of mitigation and a comprehensive set of compensation and benefit-sharing measures. At an official level, the WCD's recommendations haven't been adopted universally, for instance only influencing the World Bank's safeguarding protocols around dams (Scheumann and Hensengerth, 2014). 
However, the WCD echoes broader shifts in international development which included a growing focus on poverty reduction and sustainable development following the 1984 Bruntland Report. However, in the latest context of the widespread return of large concrete infrastructure, and not least the increase in dams, to what extent have such initiatives entailed lasting change in development practices? Is this development-policy push towards economic growth, state led development and infrastructure replicating past practices of the technician's realm? Have reformist, poverty-alleviation ideas lasted? This article analyses these questions through the Rusumo Falls Dam.

\section{NELSAP, THE WORLD BANK AND THE RUSUMO DAM}

\section{The Project's History and Implementer Nelsap}

The Kagera Basin Organisation, an institution inspired by the TVA, first pursued Rusumo

Dam. Despite numerous studies ${ }^{1}$ it was unable to initiate construction and dissolved in $2001^{2}$. However, a new and more effective organisation rose. The Nile Basin Initiative (NBI) was launched in 1999 with donor support particularly from the World Bank. The NBI quickly created two 'technical organisations (to do) ... developmental projects in ... (different) parts of the Nile'3, with the Nile Equatorial Lakes region grouped into one Subsidiary Action Program; Nelsap. As an early Nelsap leader explained, the organisation's 'mandate (was) to be a platform ... for the identification of projects and (their) preparation'4. Notably, this illustrates Nelsap's apparent purpose to aid hitherto-blocked cross-boundary initiatives, to implement development projects rather than instrumentalise a holistic framework of water governance or critical analysis of the water-energy nexus (such as that made by Verhoeven, 2015). This is further emphasised by institutional decision-making within Nelsap. The secretariat identifies projects in national governments' plans, assesses their technical engineering feasibility and attempts to forge cross-government agreement and funding 
commitments. Whilst a ministerial level steering group makes final decisions, Nelsap predominantly empowers engineering expertise with a mandate to implement infrastructure projects.

Although discussion below also demonstrates Nelsap's embrace of dam-implementation reforms, Nelsap's premise suggests that in addition, the organisation has adopted policy elements, as well as projects, from past-era river basin authorities. Nelsap is partly premised on principles of technology and human-controlled rivers as progressive, overlooking the potential value of pre-existing bio-physical systems and their livelihood and environmental services. The politics of development, the trade-offs between a project's winners and losers, are therefore refuted by discernment of the 'right' development solution. However, ideational principles are not the only factor explaining the pursuit of infrastructure and Rusumo Dam. There are few dams globally which are built across national boundaries with Itaipu and the nearby Ruzizi II ${ }^{5}$, representing rarities. Rusumo thus provides an opportunity for Nelsap to prove itself. Interviewees reflected this. A current Nelsap leader asserted that Rusumo is 'exemplary and exciting' showing the 'success of delivering infrastructure' and how the political difficulties of 'international boundaries can be overcome' through its successful 'model' ${ }^{6}$. There is a desire for Rusumo and Nelsap 'being quoted as a transboundary project that works, an exemplar, where more than one country can work together' ${ }^{7}$. Indeed, Nelsap aims 'to found a centre of excellence' ${ }^{8}$ on the back of the project's success, with 'donors now very interested in this model' of 'River Basin Excellence' ${ }^{9}$. Therefore, materialist interests co-exist with more ideational factors in Nelsap's interest in Rusumo Dam ${ }^{10 .}$

Rusumo Dam was, 'as a concept, presented and approved in 2001' by the Nelsap Ministerial Committee $^{11}$. A studying phase followed, with the World Bank showing their support financing a review of the Rusumo's existing documents. Rusumo reached final governmental approval in 2012 (Artelia, 2013a). This handed decision-making to Nelsap's technicians, 
meaning that they took key political decisions about dam design, energy transmission and mitigation. In 2013, the World Bank, after some hesitancy, agreed to finance the dam, with the African Development Bank separately funding transmission lines. The article focuses on this planning period after national governments handed over decision-making authority. The World Bank played a key role, financing construction and influencing the project's parameters because of its stringent conditionalities. We now turn to analyse these conditionalities.

\section{Reformed Practices in World Bank Finance?}

As the most comprehensive effort to investigate dams' developmental potential in a balanced way, the World Commission on Dams' relatively critical finding that $20^{\text {th }}$-Century projects underestimated significant costs and overestimated benefits, carried weight. Whilst gaining less uptake amongst developing country governments, it did influence many 'traditional' development actors. Some donors withdrew from dams (e.g. the UK), whilst Germany adopted the WCD's report (Scheumann and Hensengerth, 2014). The World Bank took a more nuanced stance, accepting the report's principles, but not its policy recommendations. This is reportedly because the Bank felt the recommendations would constrain lending activity (Moore et al., 2010). Rather, the Bank has instituted a safeguarding policy that requires a series of checks to avoid negative impacts and meet high compensation and mitigation standards (Goodland, 2010). Scheumann and Hensengerth (2014) suggest that these efforts have increased the standard of early-stage compensation, established Environmental and Social Impact Assessments (ESIAs) as the norm, and fostered practices of mitigation and specific local development schemes that aim to improve the livelihoods of affected households. This matches wider trends in the Bank during the 1990s and early 2000s that included adoption of at least the language of participation and a focus on supporting the poorest (Francis, 2001). Arguably, in accepting the need for reform, the World Bank 
appeared to cement rejection of past modernist ideas about dams' inevitable, linear connection with development.

However, such policies are not incompatible with depoliticised, expert-centric practices. It is possible to treat the safeguards as technical steps which guarantee mitigated social and environmental injustices and 'clean', 'green' hydropower projects, rather than as a process of critical thinking that helps understand and address negative impacts. For instance, the World Energy Council (2015, p. 23) downplays the fundamental trade-offs entailed by dams: 'While some impacts are unavoidable, most can be minimised or mitigated and compensated for'. Indeed critiques of mainstream participatory approaches claim that such reforms do just that, incorporating new technical steps rather than challenging practices (Francis, 2001; Hickey and Mohan, 2004). The justifications for Rusumo indicate some persistence of highmodernist ideas. For instance, a lead official stated that it was 'technically, the best solution' for a 'very hydro rich' region ${ }^{12}$. This language suggests that pursuing energy infrastructure is essentially scientifically derived; having a good engineering site and closing an electricity demand gap means Rusumo 'technically make sense' ${ }^{\text {'13 }}$. Moreover, officials described Nelsap's central role as positive because it also enables depoliticised project implementation: 'Nelsap a way of technically separating (politics) and delivering' the project ${ }^{14}$; 'Nelsap really good, process smooth ... political influence not that high ${ }^{\text {, }}$. But is such discourse reflected in the project's practices? Starting with consideration of the project's geographic context, analysis proceeds to examine the presence of a technician's realm in processes of design, knowledge production and compensation, considering whether reforms have influenced infrastructure projects today. 


\section{IMPLEMENTING RUSUMO}

\section{The Rusumo Falls Dam}

The Rusumo Falls Hydroelectric Power Project, as it is officially known, sits between the two border villages of Rusumo. These settlements, perched on spurs reaching out from hilly upland areas into a flat valley, are separated by a majestic waterfall that thunders reddish water over a 40-metre drop, creating rainbows and a permanent spray forest inhabited by a troop of monkeys. Behind the falls a vast, seasonally-covered marshland sits in the large flatbottomed valley. Each distinctive border town is on a main national road and orientated to the business of border trade and long-distance lorries carrying goods from Dar-es-Salaam.

Upstream however, agriculture predominates, and a regional culture is evident, with families and a local dialect crossing national borders. The agricultural land in the valley, whilst
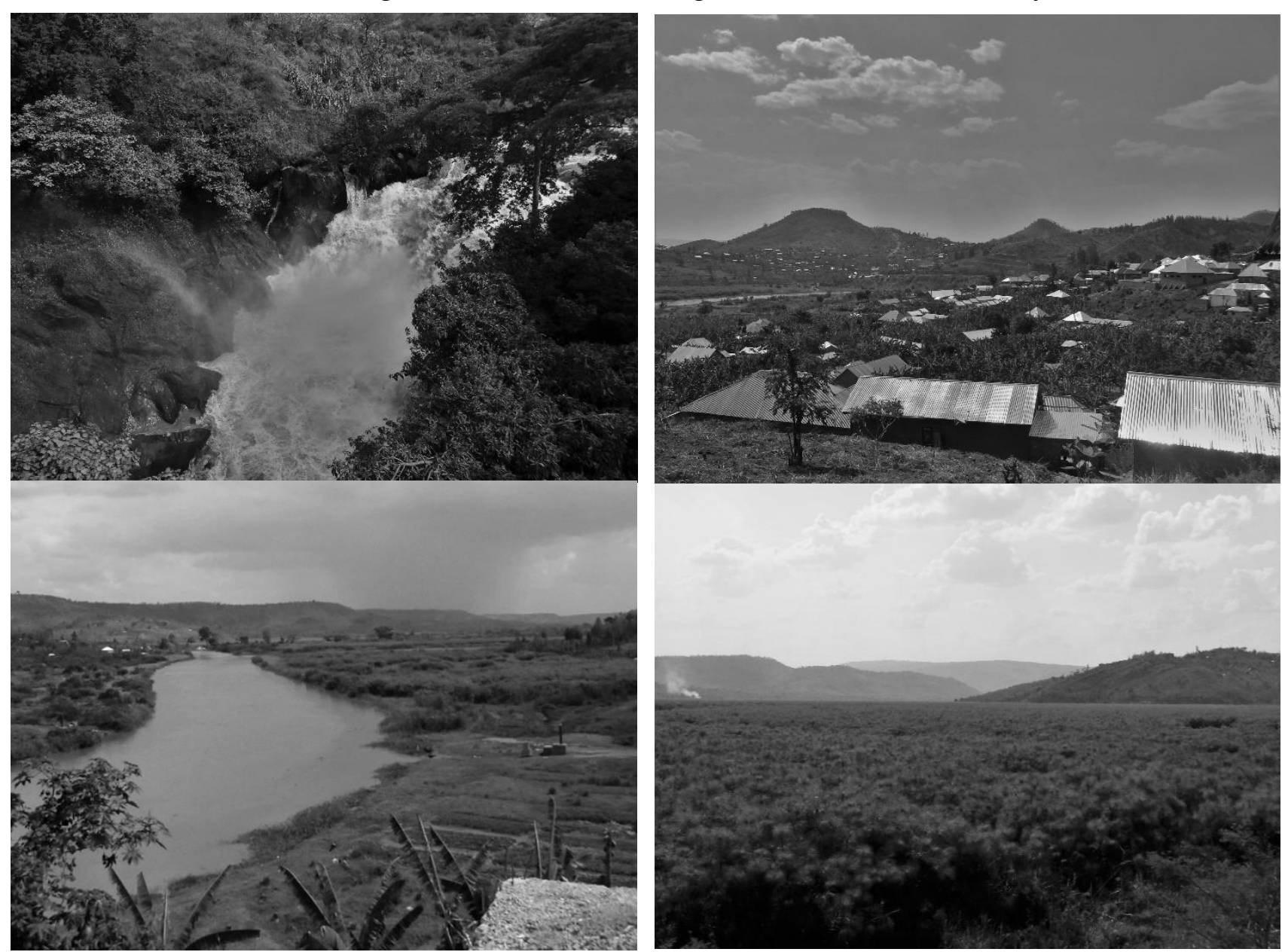

Figure 2. A Collection of Images of Rusumo Falls and the Kagera Valley: (from top left to right) Rusumo Falls; The two Rusumo Villages on each side of the river; The Kagera river above the falls (also showing water collection points); The upstream marshland 
contesting with wild animals, is rich with seasonally renewed irrigation and fertile sediment. The valley floor's dark soil and dense flora contrasts with the dry, sparse upland framing it. The US \$340 million dam will sit on top of the falls, taking advantage of their height to divert water through a tunnel and $80 \mathrm{MW}$ of electricity-generation capacity. This represents a comparatively good cost/return ratio compared with the under-construction $\$ 2.2 \mathrm{bn} 600 \mathrm{MW}$ Karuma Falls (Uganda) and is similar to the 27MW \$112 Nyabarongo Dam. National transmission lines will transport this power across the region to Rwanda, Tanzania and Burundi $^{16}$. Once completed, a relatively shallow reservoir will cover 977ha (Artelia, 2013a), displacing homes, fields and permanently flooding seasonal marsh areas. However, the project was not always planned at this size, with initial designs envisaging something far larger.

Pre-emptively following the World Bank's standards, given its early indication of support, consultants completed extensive studies from 2008. Initial engineering, economic feasibility and ESIA reports were finished in 2011. The latter indicated displacement of 17,450 households under a Full Development Scheme. In September 2011, pushed particularly by the Bank ${ }^{17}$, a 90MW Intermediate Development Scheme (IDS, see figure 3) was examined. However, its ESIA still showed displacement of 9000 households. Consequently, Nelsap and civil servants chose a third run-of-river design without reservoir storage capacity. Although this entailed lowering the dam by 5 meters, and its generation capacity to $80 \mathrm{MW}$, it reduced the number of households affected to 685 , under a $10^{\text {th }}$ of the IDS scheme. These reductions are therefore significant: The decision demonstrates reactiveness to historical experience, recognising that hydropower technology does have negative impacts and acts to significantly reduce them. 


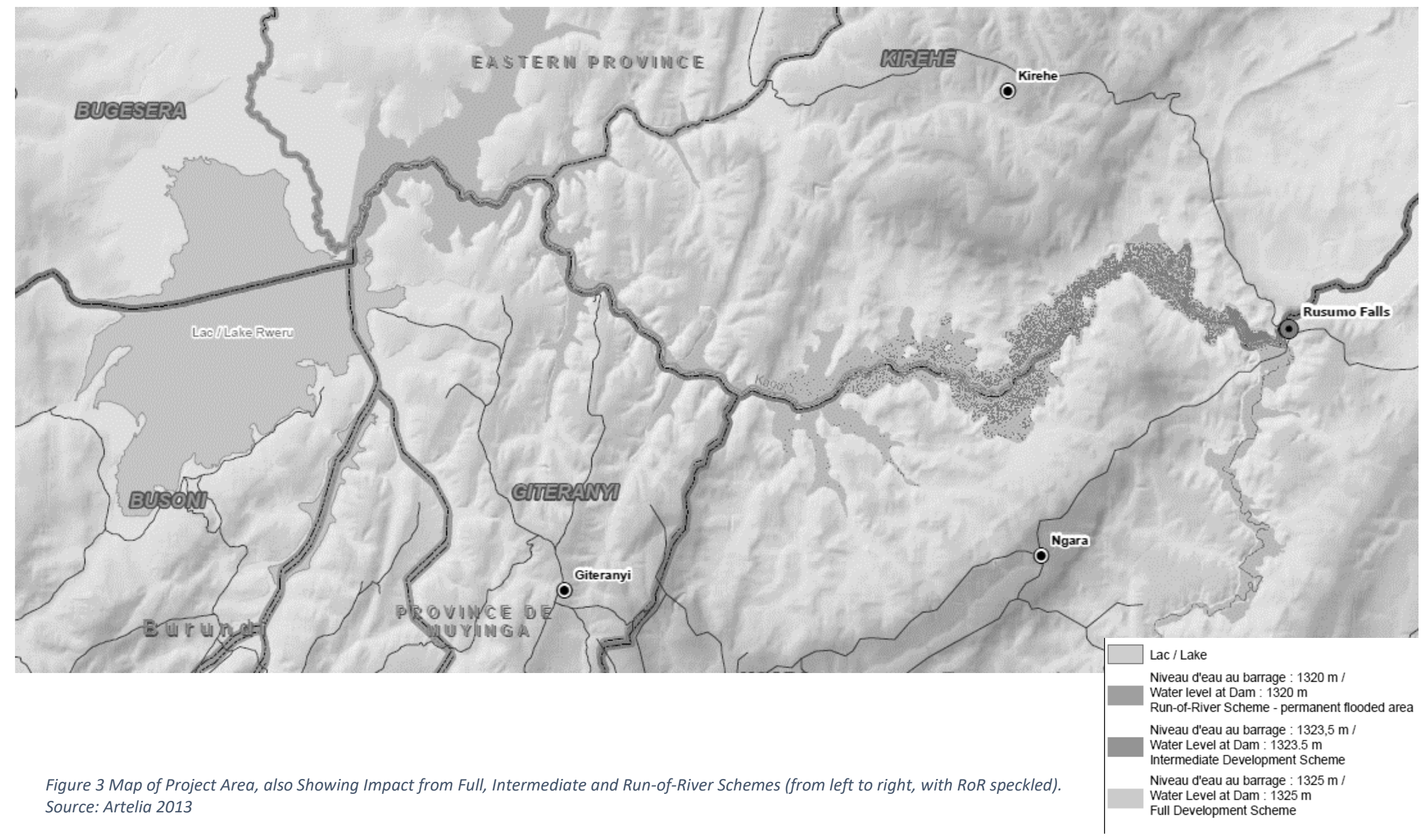


Whilst this could illustrate a political trade-off and the outcome of holistic thinking including affected communities, interviewed national civil servants depicted the revisions as a purely technical exercise. Similarly, a World Bank official described 'technical people (who find) a technical solution, ${ }^{18}$, and an involved Rwandan civil servant stated that relevant technical officials 'finally agreed on optimum size (through exclusively rational deliberation)' ${ }^{19}$. These quotes imply that Rusumo Dam's design revision was discerned by science and was therefore uncontroversial. This contrasts with the decision's apparent premise that (echoing the WCD) dams entail sufficiently negative impacts that it is worth reducing hydropower production. Nevertheless, this episode does demonstrate significant consideration of negative impacts during Nelsap and the World Bank's planning. The author knows of no comparable revision to avoid negative impacts in the past $20^{\text {th }}$ century dam-building era. Therefore, whilst decision-makers seemingly understood Rusumo's design reduction as a process of optimising to be undertaken by technicians, such practices have some significant differences with those critiqued in the past.

\section{Producing Knowledge About the Valley}

The ESIA process involved an extensive social and environmental baseline study. Whilst detailed and seemingly accurate in discreetly understanding households' activities, the ESIA misses the connections and flows between biophysical systems and livelihoods. As indicated above, the valley has two distinct economies; one based around trade along the main road and another on the river and land, especially the fertile valley floor area and land that is regularly flooded. However, these two economies are in-fact intimately connected, with many people engaging in both and the river providing drinking water, fish and fertile, irrigated agricultural land. 


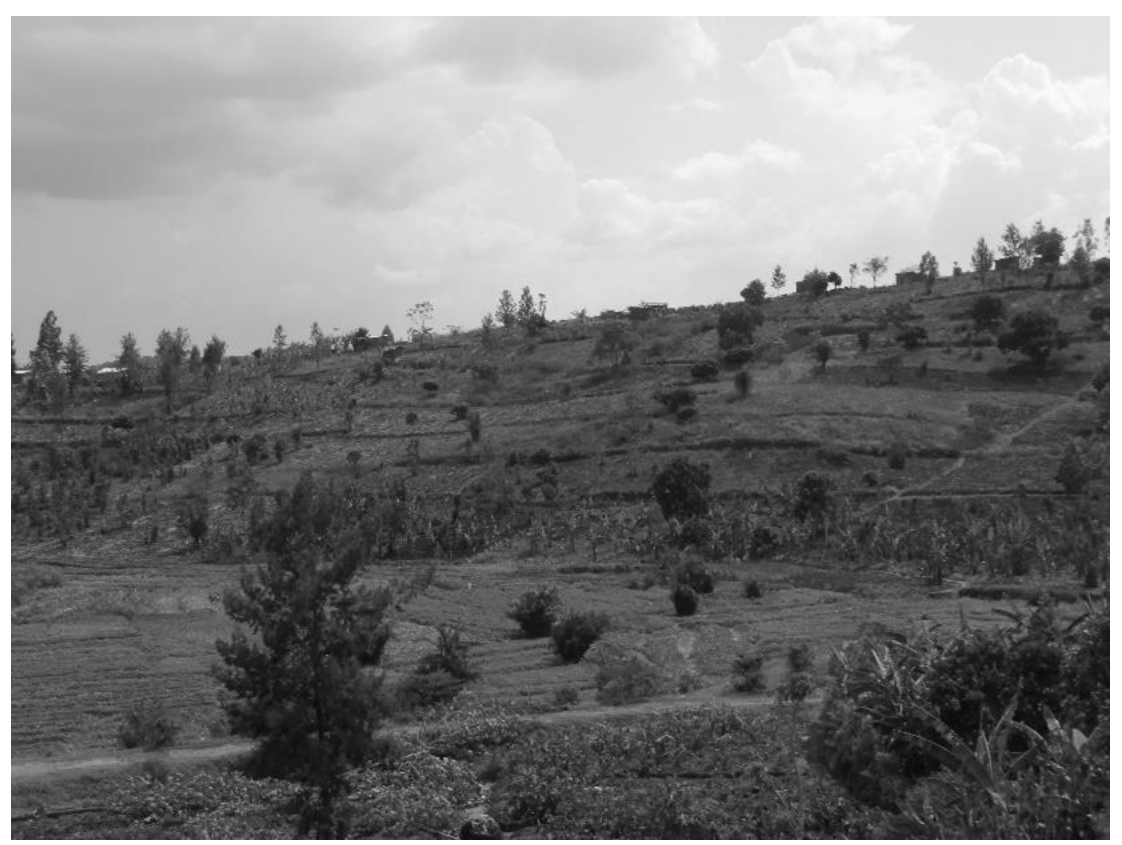

Figure 4 Farmland adjacent to the Rusumo villages: This image highlights the richer valley-floor land compared to drier, uphill land, and the different agricultural uses of each.

The fertility of land on the valley floor is currently fundamental to the volume and the variety of crop production, as surrounding dry hill land provides no equivalent conditions. For instance, in the isolated Kabuye Village, a strip of annually-flooded land was used to grow income-generating Tobacco and will now be permanently flooded. A new, narrower strip is likely to be intermittently flooded through the reservoir's rise and fall. Theoretically, the smaller strip could have similar properties to the lost land ${ }^{20}$. However, reports and interviewees had not considered this and regardless, reservoir levels would be subject to the logics of the Rusumo Power Company whose mandate concerns electricity generation and demand, reducing predictability for farmers. In interviews, up-river residents also expressed concern about the reservoir increasing habitat for hippos and monkeys which plague farmers and fishermen. The ESIA fails to mention these potential social implications and concerns.

Consequently, much of the valley's interrelated ecology and livelihood system does not appear in the ESIA. Documents record discreet facts of what is farmed, but not of how that connects to the river's hydraulic regime and how Rusumo Dam will change this biophysical system in the future. Similarly, it does not describe the gamut of connections outlined in the 
project-introduction above, between the river and valley farmers and villages. By narrowly defining 'project affected people' (PAPs) as those with directly displaced assets or jobs, the ESIA overlooks the valley's wider socio-ecology, precluding more fundamental questioning of the dam. This finding echoes Adams' (1992) writings about disconnect and narrowness in past EIAs, thereby suggesting continuity and reform within the technician's realm. Whilst the decision to down-scale shows a responsiveness absent in other dam cases discussed above, outside experts and their agendas dominate knowledge production over situated, local perspectives and values. Thus, in-line with some reformist initiatives, meaningful efforts to understand the project's locality were made, but only through a top-down, expert-orientated mode. Moreover, Usher's (1997, p. 59) 'mechanism of pervasive appraisal optimism' seems to be at work, with reports rubber stamping rather than influencing the dam's construction and adopting a 'positivist notion that (experts') ... methodology offers objective, value-free information' (Usher, 1997, p. 105). In Rusumo a pattern existed where reformist initiatives to reduce the dams and infrastructure's impact are present and, to some extent, had meaningful impact. Significant time and resources were devoted to Rusumo Dam's assessments.

However, with knowledge production interpreted as a science best wielded by experts to the exclusion of more situated understandings and perspectives, these assessments failed to meet the ideals advocated by the WCD or by individuals within the Bank ${ }^{21}$. These technician's realm practices are significant as they produced the baseline for designing compensation

\section{Providing Compensation}

In line with the World Bank's safeguards, Rusumo includes a large compensation programme. It considers land and its fertility, but also lost production and planted flora. In addition, compensation includes household and business transportation costs to support relocation and livelihood reconstruction. Moreover, as discussed below, the compensation programme included tenant farmers, accommodation renters and employees. All PAPs, in an 
effort to improve and not merely compensate, are additionally eligible for the livelihood restoration scheme and for preferential employment during construction. Rusumo's compensation adopts many of the ambitions supported by Scudder (2012), in reducing the number of PAPs and in attempting to make recipients better-off. Furthermore, practices appear to address critiques of dams as enclaves (Mohan, 2013): Rather than sealing off the construction site to local employment and procurement, shipping labour and supplies exclusively from elsewhere, this dam's stringent guidelines demand that PAPs and local residents are counted before hiring external labour and that local procurement is preferenced (Artelia, 2013b).

Many people in the valley received compensation and asserted support for the project having experienced varying gains. One household in Tanzania-Rusumo stands out in this regard. They lost land and houses to the construction site, but the male household-head had managed to re-build two houses for his different wives, and buy new land, trees and animals. A number of other Tanzanian households who have lost land and houses had built new, improved homes with their compensation money, even if they hadn't been able to buy the same quality of farmland. Additionally, interviewees described larger Rwandan asset owners of houses and shops receiving sizeable compensation sums and moving to Kigali to set up businesses in the capital's more active market. Overall, this specific focus on restoring livelihoods and the broader range of compensated items significantly contrasts with $20^{\text {th }}$ century dams described above. One well-researched example is Akosombo Dam, where displaced communities were forcibly moved to consolidated, 'modern' villages attached to large-scale, poorly-performing plantations. This left the displaced without viable livelihoods (Agbemabiese and Byrne, 2005; Miescher, 2014).

However, Rusumo's apparent compensation success masks a more complex, power-laden reality. The majority of interviewed, compensated people described losing out to varying 
degrees. One common grievance cited the rates of compensation paid, particularly in their apparent arbitrariness. One individual involved in deciding prices described how a district government team would decide rates just by viewing houses from the outside. He argued this meant the process was subjective and uninformed, preventing the establishment of 'proper' values $^{22}$. Moreover, the calculation of yields used statistics provided by local authorities, based on generalised land types (Artelia, 2013a), thus excluding each farms' particular conditions and the knowledge of landowners. This demonstrates an invisiblising of metis, meaning the situated knowledge and values which land prices might ordinarily capture (Scott, 1998). Moreover, many people asserted the difficulty of finding replaceable land. This stems from the contrast between appropriated rich valley-floor agricultural plots and drier, sparse uplands. This was particularly problematic in densely-populated Rwanda. However, this concern does not feature in considerations of the dam's impact, or in resettlement plans.

In addition, whole groups seem to have been largely overlooked including the poorer spectrum of tenant farmers, house renters and business employees. All were supposed to be recognised by the compensation process and included in meetings and the livelihood restoration program. Additionally, tenant farmers were supposed to receive compensation for the labour they had put into the land (including improvements like irrigation systems), growing plants and the value of one year's yield. Residential renters were allocated financial support with three month's fees and transportation costs. Meanwhile, formally organised fishermen, brick makers and other employees were due two months' pay through their employer or cooperative (Artelia, 2013a, pp. 3; 5). However, the fieldwork found few enrolled in this way, and many who been missed. For instance, the fieldwork specifically found that the compensation planning process miscalculated the number of fishermen, tenant farmers and residents and those using marshland that will be flooded by the reservoir. This stemmed from the way in which the baseline report and compensation design did not 
sufficiently understand livelihoods and involved limited participation of affected peoples, whose knowledge and perspectives could have acted as a corrective. One typical household had rented valley-floor farmland and a house but had received no direct communication from project officials. Rather their landlord, who was enrolled in the compensation scheme, told them they needed to leave. This left them one year on, with a smaller, lower quality home and no farmland ${ }^{23}$. Another example included farmers on the upstream Rwanda side who were renting land that had been compensated. They were growing beans in the future reservoir area but only their landlady, and not project officials, had contacted them ${ }^{24}$.

Improper counting was also apparent for brickmaking and fishing employees and cooperative members. The census for this group seemed to understate their numbers and include the wrong people. The ESIA records 14 fishermen as being present in the valley (Artelia, 2013a) but my interviews indicated that this number was much larger, with just one group of Tanzanian fishermen stating that their cooperative was 25 strong. Additionally, a large number of people on both sides of the valley reported fly-fishing as one of their main activities. This discrepancy could stem from fishing being a predominantly wet season occupation. Reportedly this season's volume of water, as well as increased numbers of insects, makes fly-fishing easier. Thus, a potential misunderstanding of local livelihoods, lack of rigor or, as some suggested, corruption in enrolling people, has meant a large number of interviewed fishermen did not receive compensation and were not enrolled as PAPs. Therefore, a pattern of missing renters, wage labourers and more marginal communities exists. This suggests the significance of the limited impact assessment and uncomprehensive efforts to record potentially affected people. On paper, a grievance mechanism was supposed to resolve such problems. However, the only meaningful action taken by the mechanism seems to have come in its first tier, where a committee made of PAPs was able to settle landborder disputes: No money was allocated for solving cases and the final tier of courts were 
not viewed as a realistic possibility by interviewees, who cited issues of literacy, confidence and know-how ${ }^{25}$.

Overall, this analysis demonstrates unequal outcomes far from the comprehensive compensation asserted by Nelsap technicians and official reports. A considerable proportion rebuilt livelihoods and even experienced improvements, particularly in terms of house quality. However, echoing the nearby World Bank-financed 1980s Ruzizi II Dam that dramatically understated the number of affected people by approximately $15,000^{26}$, many others, especially those with less power, appear to have been excluded. This ranged from fishermen, where surveys appeared to underestimate those involved in this seasonal activity, to tenant farmers and renters who were simply missed. The sole reliance on one-off surveys by outside technicians, without sustained participation, provides one explanation for this. Rather than the apolitical veneer of compensation, this would suggest a misunderstood and strongly political process with the more powerful securing better deals than the economically marginalised.

\section{Consulting the people and Developing Livelihoods}

The RAP asserted principals of participation: 'In line with the relevant international requirements, consultation with, and participation of, affected communities and individuals are key elements of the RAP development and implementation process'(Artelia, 2013b, p. r). In line with this, elected local community members joined international Nelsap conferences during Rusumo Dam's planning phase. One of the Tanzanian Rusumo representatives appears to have been particularly active in calling for adjustments to the project's compensation process and in asserting implementation ideas, suggesting compensation for fishermen and brick makers ${ }^{27}$. Once the project had been approved in 2012, a more active series of meetings with the various villages began. This involved convening large groups to explain the project and give opportunities for questions ${ }^{28}$. Another method of 'participation' 
involved appointing Rwandan and Tanzanian committees of PAPs. These could have been a vehicle for delegation or collaboration in decision-making, or a tool for PAPs to raise concerns and advocate change. Rather, the committees were primarily used for implementation: Their main function was to organise and educate, and in the grievance mechanism explained above. Individual instances of consultation have occurred, but PAPs involvement wouldn't rank as above 'collaboration' or 'partnership' in conceptual models, a composite of which are depicted in figure 5 (Shipley and Utz, 2012, pp. 30-31). Therefore, whilst inclusion attempts appear limited. Even the most involved Nelsap conference representative was on-balance critical of the project, citing its lack of participation. This is significant given the corrective role potentially played by participation in ensuring the capture of affected peoples and in improving compensation and mitigation measures.

The disconnect between the project's participative aims and practise is well illustrated by the Livelihood Restoration Scheme. The scheme originates in World Bank principles of improving affected peoples livelihoods. Additionally, it served as an alternative to

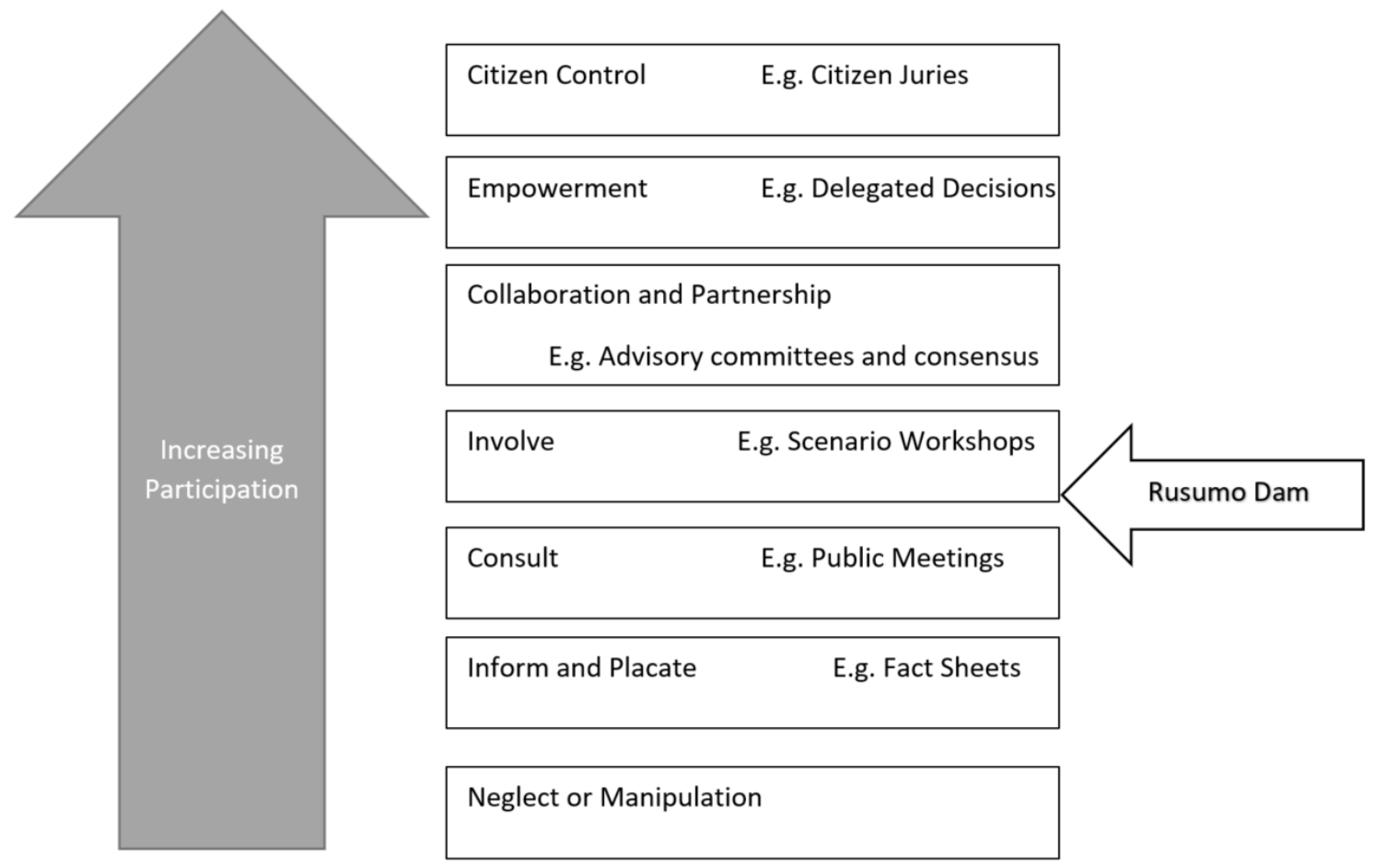

Figure 5 Composite of participatory models reviewed by Shipley and Utz (2012, p 30-31). Including the International Association of Public Participation and Arnstein (1969) 
compensation for renters, tenants and employees, none of whom were losing formally owned assets. Additionally it supported those using the legally ambiguous seasonally flooded marshland ${ }^{29}$ (which is illegal to use on the Rwandan side and varyingly recognised as legitimate in Tanzania). Using the scheme as compensation assumes the straightforwardness of doing development, that one can easily create new and improved livelihoods. From the critical development studies school, such an assumption ignores the problematic history of immanent, externally-initiated rural development attempts (e.g. Ferguson, 1994). Nevertheless, Nelsap offers a range of programmes, from agricultural crop support, to business development and livestock rearing (Artelia, 2013b). Consultations with the resettlement committees shaped these final offerings ${ }^{30}$, but the scheme was primarily decided before local engagement by consultants undertaking the RAP. Their primary influence came from regional district government officers and secondarily, from regional NGOs (Artelia, 2013b).

Most interviewees involved in the Livelihood Restoration Scheme strongly critiqued it. Apart from not being enrolled, interviewees complained that the scheme was top-down and unresponsive. Officially registered PAPs (which as we have seen excludes many directly losing from the dam), were supposed to be able to choose which programme to enrol in, but a number of Tanzanian-Rusumo interviewees denied having such a choice. When it came to the Scheme's implementation, the choice of specific animals for instance, or feedback on what did and didn't work, interviewed current committee members and enrolled PAPs felt powerless. A useful illustration here comes from one of the main programs involving livestock rearing. Interviewees critiqued the use of non-local cow breeds because of poor husbandry knowledge among recipients and because these cows were unsuited to the dry season's poor-quality grass and lack of water. Household $14 \mathrm{Tz}$ described how a cow consequently died within a year. Similarly, a number of interviewees expressed 
powerlessness. The head of one family was especially angry with the rabbit program which he felt he had no choice over, exclaiming 'why do we have these fucking rabbits?!'31. Fundamentally, whilst having gained a better-quality house, he cared about the land they had been unable to replace: For them rabbits would not bring a livelihood foundation, or even useful diversification. Such shortcomings appear particularly problematic given that the restoration scheme is supposed to function as compensation for those with unrecognised/informal land ownership. Whilst the presence of the RAP is notable, representing a significant departure from past dam building practices with an attempt to spread local benefits, the restoration scheme echoes classic development critiques involving attempts to change livelihoods with limited input from recipients, questionable appropriateness and the empowerment of experts. Arguably, this would have been avoided had the recipients had a stronger role in shaping the programme and if the scheme's planners had paid more attention to local knowledge and the valley's specificities, rather than implementing essentially pre-decided national plans. Echoing Li (2007), the RAP severed as a tool to render livelihoods technical, focusing on symptoms (e.g. absent livestock assets) not poverty's social causes. 
CONCLUSIONS: REFORMED TECHNICIAN'S REALM?

\begin{tabular}{|c|c|c|c|}
\hline $\begin{array}{l}\text { Dam Building } \\
\text { Policy Process }\end{array}$ & $\begin{array}{l}\text { Reformist Policy } \\
\text { Measures }\end{array}$ & $\begin{array}{l}\text { Implementation } \\
\text { in Rusumo } \\
\text { Dam }\end{array}$ & Effectiveness \\
\hline \multirow[t]{2}{*}{$\begin{array}{l}\text { Knowledge } \\
\text { production }\end{array}$} & \multirow{2}{*}{$\begin{array}{l}\text { More detailed and } \\
\text { systems-based } \\
\text { survey of livelihood } \\
\text { and environmental } \\
\text { baseline conditions; } \\
\text { Consideration of } \\
\text { impacts across } \\
\text { environmental and } \\
\text { social systems; }\end{array}$} & \multirow[t]{2}{*}{$\begin{array}{l}\text { Wide-ranging, } \\
\text { detailed surveys } \\
\text { with multiple } \\
\text { experts over } \\
\text { three years }\end{array}$} & $\begin{array}{l}\text { Detailed assessment of livelihoods but } \\
\text { not of interrelationships between } \\
\text { riverine and livelihood systems nor of } \\
\text { long-term upstream and downstream } \\
\text { effects }\end{array}$ \\
\hline & & & $\begin{array}{l}\text { No consideration of replace-ability of } \\
\text { seasonally flooded land }\end{array}$ \\
\hline \multirow{2}{*}{$\begin{array}{l}\text { Design and } \\
\text { Operation } \\
\text { Mitigation }\end{array}$} & \multirow{2}{*}{$\begin{array}{l}\text { Change the design of } \\
\text { the physical } \\
\text { infrastructure and its } \\
\text { operation to reduce } \\
\text { impacts }\end{array}$} & \multirow{2}{*}{$\begin{array}{l}\text { Dam revised } \\
\text { from storage } \\
\text { reservoir to run- } \\
\text { of-river scheme }\end{array}$} & $\begin{array}{l}\text { Reduced number of affected people } \\
\text { from } 17,450 \text { to } 685\end{array}$ \\
\hline & & & Did not consider operation mitigation \\
\hline \multirow[t]{4}{*}{ Compensation } & \multirow{4}{*}{$\begin{array}{l}\text { Holistic } \\
\text { compensation } \\
\text { moving beyond } \\
\text { assets to livelihoods }\end{array}$} & \multirow{4}{*}{$\begin{array}{l}\text { Broad } \\
\text { compensation } \\
\text { including } \\
\text { moving and } \\
\text { production costs }\end{array}$} & $\begin{array}{l}\text { Majority who received saw as broadly } \\
\text { fair }\end{array}$ \\
\hline & & & Issue with recognising fertility of land \\
\hline & & & $\begin{array}{l}\text { Issue with being able to replace } \\
\text { seasonally flooded zone }\end{array}$ \\
\hline & & & $\begin{array}{l}\text { Some affected left out- particularly } \\
\text { renters }\end{array}$ \\
\hline \multirow[t]{3}{*}{$\begin{array}{l}\text { Livelihood } \\
\text { Restoration } \\
\text { Scheme }\end{array}$} & \multirow{3}{*}{$\begin{array}{l}\text { Establish new } \\
\text { livelihoods for } \\
\text { affected people and } \\
\text { diversify income } \\
\text { sources }\end{array}$} & \multirow{3}{*}{$\begin{array}{l}\text { Created } \\
\text { livelihood } \\
\text { projects based } \\
\text { on international } \\
\text { consultant } \\
\text { reports and } \\
\text { district } \\
\text { authorities }\end{array}$} & $\begin{array}{l}\text { Some proposed projects deemed } \\
\text { useful by interviewees (e.g. fishing). } \\
\text { Others contested (e.g. cloths } \\
\text { shops/rabbit keeping) }\end{array}$ \\
\hline & & & $\begin{array}{l}\text { Opaque process of enrolment in } \\
\text { schemes; Corruption alleged; Affected } \\
\text { households missed out }\end{array}$ \\
\hline & & & $\begin{array}{l}\text { Limited participation in designing the } \\
\text { scheme and ensuring its relevance }\end{array}$ \\
\hline Participation & $\begin{array}{l}\text { Increase the } \\
\text { involvement of local } \\
\text { communities to } \\
\text { reduce negative } \\
\text { impact and ensure } \\
\text { relevance }\end{array}$ & $\begin{array}{l}\text { Created local } \\
\text { committees of } \\
\text { officially } \\
\text { affected people; } \\
\text { held regular } \\
\text { meetings with } \\
\text { affected peoples; } \\
\text { conducted } \\
\text { consultative } \\
\text { surveys }\end{array}$ & $\begin{array}{l}\text { Did not meet standards of } \\
\text { 'participation', more 'consultation'; } \\
\text { the local committees acted mostly to } \\
\text { disseminate and organise }\end{array}$ \\
\hline \multirow[t]{3}{*}{$\begin{array}{l}\text { Benefit } \\
\text { Sharing }\end{array}$} & \multirow[t]{3}{*}{$\begin{array}{l}\text { Share the benefits of } \\
\text { the dam with } \\
\text { affected communities }\end{array}$} & \multirow{3}{*}{$\begin{array}{l}\text { Spent US } \$ 15 \mathrm{~m} \\
\text { on a benefit fund } \\
\text { for the districts } \\
\text { affected by the } \\
\text { original dam } \\
\text { design. }\end{array}$} & $\begin{array}{l}\text { Spending decided by District } \\
\text { governments without village level } \\
\text { input; spending opposite to perceived } \\
\text { priorities in Tanzania-Rusumo }\end{array}$ \\
\hline & & & $\begin{array}{l}\text { Money spread over large area so little } \\
\text { will reach the affected villages }\end{array}$ \\
\hline & & & $\begin{array}{l}\text { No plan for long-term benefit sharing } \\
\text { directly from the dam/the Rusumo } \\
\text { Power Corporation }\end{array}$ \\
\hline
\end{tabular}

Figure 6 Summary of reformist principles and their implementation in the Rusumo Dam project 
This analysis of Rusumo Falls Dam therefore contributes to debates in development studies on the increasing infrastructure turn and the practices that trend involves. The dam demonstrates the influence of the World Bank's more stringent safeguards in pushing reformist policies, evidenced here by the degree of people, assets and activities compensated for, but also in terms of the attention on measuring impacts. These efforts attempt to address past academic and policy critiques of disconnect between dam implementing technicians and the infrastructure's negative socio-ecological outcomes. Indeed the intention to leave PAPs better off follows Scudder's (2012) recommendation and favourably contrasts with the upstream Rwandan Nyabarongo Dam: Nyabarongo's compensation was less generous and the range of people included, far smaller (Dye, 2016). Past dam critiques also influenced mitigation principals that led to the striking revision of Rusumo's size, involving a 25-fold reduction in directly affected households compared to the initial full development scheme. Such findings mark Rusumo out from most historic dams, indicating some of the differences that exist in the present-day infrastructure construction trend: There are increasingly established practices of ambitious impact assessment, mitigation and compensation.

However, amongst such meaningful reform, a technician's realm appears to have persisted in the Rusumo project, leading to a number of negative outcomes. Despite the language of participation and holistic assessment, Nelsap and local officials and consultants predominantly undertook decision-making, understanding impacts as discreet, not as a connected socio-ecological system. Even if Rusumo does represent a 'good' infrastructure option of development potential with small socio-ecological impact, such an openly political appraisal embracing likely trade-offs was absent. Rather, the decision making process rendered development as technical: The dam became the scientifically derived 'right' solution. Implementation was treated as a process whose key decisions should be made by consultants, Nelsap engineers and regional government experts as they could scientifically 
discern optimal outcomes by following 'best practices' to understand the valley, direct compensation and divine local development. The result of these technician's-realm practices, was the underestimation of impacts and over-estimation of compensation efforts. This trend is significant given the important rise in infrastructure construction. On the one hand, it suggests the continued relevance of well-established critiques of development. Despite the decades since Chambers, Ferguson and Scott's seminal works, or the establishment of criticisms on participation (Hickey and Mohan, 2004), these analytical lenses remain insightful. Although a new veneer of sustainable development policy exists, the imbalances in power, shortcomings in knowledge production and short-sightedness entailed by the technician's realm results in a familiar pattern of winners and losers along social cleavages of wealth, geography and status.

However, this article's demonstration of influential reformist mitigation policies also suggests that change has happened. Here, echoing Chen and Landry (2018), the World Bank pushed adoption of reformist policies concerning impact assessment, mitigation and compensation and, equally importantly, acted to enforce them. Such evidence contrasts with Goldman (2005) whose unsympathetic account simply paints the Bank as rendering the environment an exploitable natural resource and its attempts at participation, a farce. This study suggests that to some extent the Bank has learned and responded to past issues with dam building. Therefore, this case indicates the need for nuanced analysis of the growing wave of infrastructure construction because its practices of knowledge production and mitigation, and its related socio-ecological impacts, aren't mere replication of the past mid$20^{\text {th }}$ Century dam-building era. Therefore, differences in reformist-policy adoption could cause significant variation in the present-day infrastructure turn. As the so-called traditional development actors return to direct engagement in infrastructure, and as new institutions such as Nelsap are created to increase construction, the ambition and stringent enforcement of 
practices around impact assessment, mitigation and benefit sharing will be particularly important.

I believe this article entails no conflict of interest.

\section{ENDNOTES}

${ }^{1}$ Agriculture (1979), engineering-feasibility (1987-1992) and environmental impacts (1993)

2 Interviewee 1

${ }^{3}$ Interviewee 1

${ }^{4}$ Interviewee 1

${ }^{5}$ On the Paraguay-Brasil and D.R. Congo-Rwanda borders respectively

${ }^{6}$ Interviewee 5

${ }^{7}$ Interviewee 1

${ }^{8}$ Interviewees 1,2

${ }^{9}$ Interviewee 5 . Echoed by interviewees 1,2

${ }^{10}$ Interviewee 5

${ }^{11}$ Interviewee 1

${ }^{12}$ Paraphrased Interviewee 11

${ }^{13}$ Paraphrased Interviewee 11, 15

${ }^{14}$ Interviewee 16

${ }^{15}$ Interviewee 10

${ }^{16}$ Reflecting policies for increased East Africa Community electricity trade (e.g. EAC 2018 Sustainability Policy)

${ }^{17}$ According to interviewees $12,13,14$

${ }^{18}$ Interviewees 11,15

${ }^{19}$ Interviewee 9

${ }^{20}$ As Zambia's Kariba demonstrates (Scudder, 2012)

${ }^{21}$ Interview 14

${ }^{22} \mathrm{Tz} 26$

${ }^{23} 34 \mathrm{Tz}$

${ }^{24} 14 \mathrm{Rw}$

${ }^{25}$ In contrast to interviewees $1,2,3,4,5,6,7$ were $14 \mathrm{Tz}, 26 \mathrm{Tz}$ and $27 \mathrm{Tz}$. Local interviewees appeared unaware of supposed financial support; This finding echoes other Bank projects like Nam Theun II (Goldman, 2005)

${ }^{26}$ Initially calculated at 135 , with revisions demonstrating 15,000 were in-fact affected (McCully, 2001)

${ }^{27} 25 \mathrm{Tz}$

${ }^{28}$ Interviewees $1,2,3,4,5,6,7 ; 10 \mathrm{Tz}, 12 \mathrm{Tz}, 13 \mathrm{Tz}$

${ }^{29}$ Interviewees 1,2,3,4, 5, 6, 7; Artelia, 2013a

${ }^{30} 26 \mathrm{Tz}, 27 \mathrm{Tz}$

${ }^{31}$ Paraphrased interviewee $14 \mathrm{Tz}$ 


\section{Appendix: Interviews}

\section{Local Level Interviews Cited}

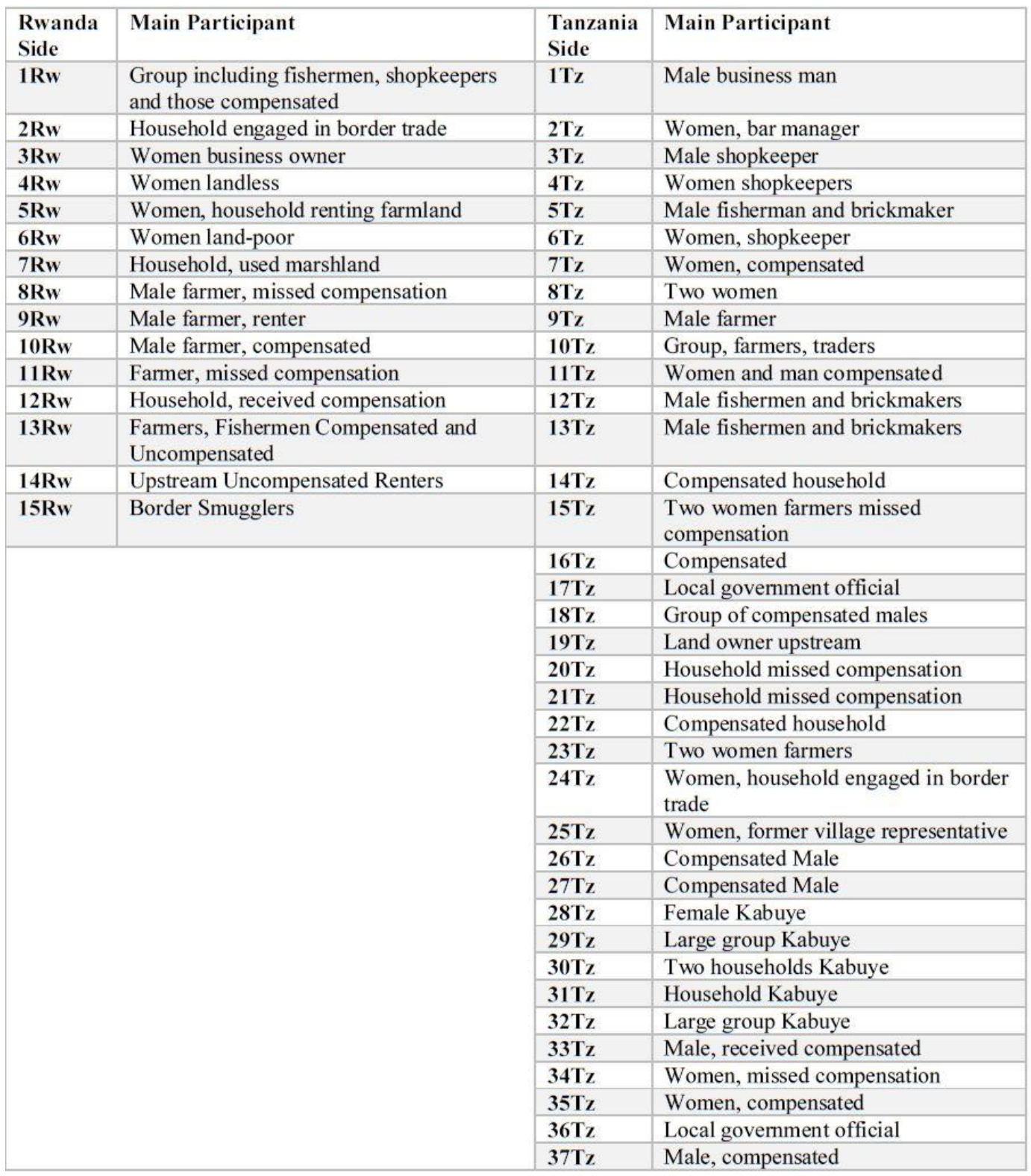




\section{Quoted Rusumo Dam Planners}

\begin{tabular}{|c|c|c|c|}
\hline Organisation & Position & Number & Date \\
\hline \multirow{8}{*}{ NELSAP } & Former Senior Leader & 1 & August, 2016 \\
\hline & Senior Leader & 2 & September, 2015 \\
\hline & Engineer & 3 & August, 2016 \\
\hline & Programme Officer & 4 & September, 2015 \\
\hline & Programme Officer & 5 & September, 2015 \\
\hline & Project Manager & 6 & September, 2015; August, 2016 \\
\hline & $\begin{array}{l}\text { Project Coordinator and Social } \\
\text { Lead }\end{array}$ & 7 & October, 2017 \\
\hline & Manager & 8 & August, 2016 \\
\hline $\begin{array}{l}\text { Rwandan } \\
\text { Energy Utility } \\
\text { EDCL }\end{array}$ & Senior Official & 9 & August, 2016 \\
\hline \multirow{5}{*}{ World Bank } & Manager & 10 & September, 2015; August, 2017 \\
\hline & Senior Hydropower Specialist & 11 & August, 2017 \\
\hline & Senior Hydropower Specialist & 12 & August, 2017 \\
\hline & Senior Safeguards Official & 13 & August, 2017 \\
\hline & Energy Specialist & 14 & September, 2015; August, 2017 \\
\hline
\end{tabular}

\section{REFERENCES}

Adams, W. M. (1992) Wasting the rain: rivers, people and planning in Africa. London: Earthscan. Agbemabiese, L., and Byrne, J. (2005) Commodification of Ghana's Volta River: An Example of Ellul's Autonomy of Technique. Bulletin of Science, Technology \& Society 25(1): 17-25.

Artelia (2013a) Rusumo Falls Hydroelectric Project-Dam and Powerplant Component:

Environmental and Social Impact Assessment (ESIA): Volume 1: Main Report, No. E4144v1.

Echirolles, France: Nile Basin Initiative (NBI)/ Nile Equatorial Lakes Subsidiary Action Program (NELSAP).

Artelia (2013b) Rusumo Falls Hydroelectric Project- Dam and Powerplant Component: Resettlement Action Plan (RAP): Volume 1: Main Report, No. EP1411v1. Echirolles, France: Nile Basin Initiative (NBI)/ Nile Equatorial Lakes Subsidiary Action Program (NELSAP).

Baird, I. G., Shoemaker, B. P., and Manorom, K. (2015) The People and their River, the World Bank and its Dam: Revisiting the Xe Bang Fai River in Laos: The People and their River Revisited.

Development and Change 46(5): 1080-1105. 
Byrne, J., and Toly, N. (2006) Energy as a Social Project: Recovering a Discourse. In Byrne, J., Toly, N., and Glover, L. (Eds.), Transforming Power: Energy, Environment, and Society in Conflict. New Brunswick, N.J: Transaction Publishers.

Chen, Y., and Landry, D. (2018) Capturing the rains: Comparing Chinese and World Bank hydropower projects in Cameroon and pathways for South-South and North South technology transfer. Energy Policy 115: 561-571.

Dye, B. (2016) The return of 'high modernism'? Exploring the changing development paradigm through a Rwandan case study of dam construction. Journal of Eastern African Studies 10(2): 303324.

Ellul, J. (1964) The technological society: a penetrating analysis of our technical civilization and of the effect of an increasingly standardized culture on the future of man. New York, NY: Vintage books.

Ferguson, J. (1994) The anti-politics machine: 'development,' depoliticization, and bureaucratic power in Lesotho. Minneapolis: University of Minnesota Press.

Francis, P. (2001) Participatory Development at the World Bank: The primacy of Process. In Cooke, B. and Kothari, U. (Eds.), Participation: The New Tyranny? London ; New York: Zed Books.

Goldman, M. (2005) Imperial nature: the World Bank and struggles for social justice in the age of globalization. New Haven, Conn. ; London: Yale University Press.

Goodland, R. (2010) The World Commission on dams +10: Revisiting the large dam controversy. Water Alternatives 3(2): 384-398.

Harrison, G. (2001) Post-Conditionality Politics and Administrative Reform: Reflections on the Cases of Uganda and Tanzania. Development and Change 32(4): 657-679.

Hart, G. (2001) Progress reports Development critiques in the 1990s: culs de sac and promising paths. Progress in Human Geography 25(4): 649-658.

Hickey, S., and Mohan, G. eds. (2004) Participation, from tyranny to transformation? exploring new approaches to participation in development. London; New York: New York: ZED Books ; Distributed exclusively in the U.S. by Palgrave Macmillan. 
Kaika, M. (2006) Dams as Symbols of Modernization: The Urbanization of Nature Between Geographical Imagination and Materiality. Annals of the Association of American Geographers 96(2): $276-301$.

Klingensmith (2007) 'One valley and a thousand': dams, nationalism, and development. New Delhi: Oxford University Press.

Lerner, D. (1958) Passing of traditional society: modernizing the middle east. Place of publication not identified: Macmillan Pub Co.

Leys, C. (1996) The rise \& fall of development theory. Nairobi : Bloomington: EAEP ; Indiana University Press.

Li, T. M. (2007) The will to improve: governmentality, development, and the practice of politics. Durham: Duke University Press.

Mawdsley, E. (2018) The 'Southernisation' of development?: The 'Southernisation' of development? Asia Pacific Viewpoint 59(2): 173-185.

Miescher, S. F. (2014) 'No one should be worse off': The Akosombo dam, modernisation and the experience of resettlement in Ghana. In Bloom, P. J., Miescher, S., Manuh, T., and Hintzen, P. C. (Eds.), Modernization as Spectacle in Africa. Bloomington: Indiana University Press.

Mohan, G. (2013) Beyond the Enclave: Towards a Critical Political Economy of China and Africa. Development and Change 44(6): 1255-1272.

Molle, F., Mollinga, P., and Wester, P. (2009) Hydraulic Bureaucracies and the Hydraulic Mission: Flows of Water, Flows of Power. Water Alternatives 2(3): 323-349.

Moore, D., Dore, J., and Gyawali, D. (2010) The World Commission on Dams +10: Revisiting the Large Dam Controversy. Water Alternatives 3(2): 3-13.

Nugent, P. (2018) Africa's re-enchantment with big infrastructure: White elephants dancing in virtuous circles? In Schubert, J., Engel, U., and Macamo, E. S. (Eds.), Extractive Industries and Changing State Dynamics in Africa: Beyond the Resource Curse (First Edition.). New York: Routledge.

Rist, G. (2010) The history of development: from Western origins to global faith. (3. ed., 2. impr.). London: Zed Books. 
Rostow, W. W. (1960) The stages of economic growth: a non-communist manifesto. (3rd ed.).

Cambridge [England] ; New York: Cambridge University Press.

Scheumann, W., and Hensengerth, O. (2014) Dams and Norms: Current Practices and the State of the Debate. In Scheumann, W. and Hensengerth, O. (Eds.), Evolution of Dam Policies: Evidence from the Big Hydropower States. Berlin, Heidelberg: Springer Berlin Heidelberg doi:10.1007/978-3-64223403-3_1.

Schumacher, E. F. (1993) Small is beautiful: a study of economics as if people mattered. London: Vintage Books.

Scott, J. C. (1998) Seeing like a state: how certain schemes to improve the human condition have failed. New Haven, Conn.: Yale Univ. Press.

Scudder, T. (2012) Resettlement Outcomes of Large Dams. In Tortajada, C., Altinbilek, D., and Biswas, A. K. (Eds.), Impacts of Large Dams: A Global Assessment. Berlin, Heidelberg: Springer Berlin Heidelberg doi:10.1007/978-3-642-23571-9_3.

Shipley, R., and Utz, S. (2012) Making it Count: A Review of the Value and Techniques for Public Consultation. Journal of Planning Literature 27(1): 22-42.

Singh, S. (2002) Taming the waters: the political economy of large dams in India. New Delhi; New York: Oxford University Press.

Stiglitz, J. E. (2002) Globalization and its discontents. London: Penguin Books.

Usher, A. D. (1997) The mechanism of 'pervasive appraisal optimism'. In Usher, A. D. (Ed.), Dams as Aid: A Political Anatomy of Nordic Development Thinking. London ; New York: Routledge.

Verhoeven, H. (2015) The nexus as a political commodity: agricultural development, water policy and elite rivalry in Egypt. International Journal of Water Resources Development 31(3): 360-374. World Energy Council (2015) World Energy Resources: Charting the Upsurge in Hydropower Development 2015. World Energy Council: London.

Zarfl, C., Lumsdon, A. E., Berlekamp, J., Tydecks, L., and Tockner, K. (2015) A global boom in hydropower dam construction. Aquatic Sciences 77(1): 161-170. 